\title{
ADDRESSING SHORTFALlS IN TRADITIONAL LEgAL EDUCATION: \\ UT'S CONCENTRATIONS AND CAPSTONES AND WALler LaNSDEN's SCHOla2Juris Program
}

\author{
GEORGE W. KUNEY* \& JOSEPH WATSON**
}

\section{INTRODUCTION}

Law school's traditional educational model needs to be revamped. The traditional law firm's summer associate model needs restructuring. Some might say they are both broken. ${ }^{1}$ Across the country, educators and commentators are talking about legal education reforms, and leading law firms are confronting how to improve the age-old mechanism for recruiting law students. ${ }^{2}$

\footnotetext{
* George W. Kuney is a Lindsay Young Distinguished Professor of Law and, for 13 years, has served as the Director of the James L. Clayton Center for Entrepreneurial Law at The University of Tennessee College of Law, which administers the college's Concentration in Business Transactions. The Center and the Concentration were founded in 1995. http://www.law.utk.edu/people/george-w-kuney/; http://law.utk.edu/centers-clinics/claytoncenter/. He can be reached at gkuney@utk.edu. He thanks Dakotah Brown (UT Law class of 2015) for his research assistance on this article, and Professor Penny White for her contributions regarding the concentration in advocacy and dispute resolution.
}

** Joseph Watson is an attorney in private practice associated with Waller Lansden Dortch \& Davis, LLP. Mr. Watson previously clerked for Tennessee Supreme Court Justice Gary Wade and received his J.D. from The University of Tennessee College of Law in 2011.

${ }^{1}$ Ethan Bronner, A Call for Drastic Changes in Educating New Lanyers, N.Y. TiMES, Feb. 11, 2013, at A11, available at http://www.nytimes.com/2013/02/11/us/lawyers-call-for-drastic-change-ineducating-new-lawyers.html ("There is almost universal agreement that the current system is broken. ... At the [American Bar Association's Task Force on Future of Legal Education's] hearing, where lawyers and students gave testimony, most said the time was ripe for that change.").

2 David Segal, What They Don't Teach Law Students: Lanyering, N.Y. TimES, Nov. 20, 2011, at A1, available at http://www.nytimes.com/2011/11/20/business/after-law-school-associates-learn-tobe-lawyers.html (“'We should be teaching what is really going on in the legal system,' says Edward L. Rubin, a professor and former dean at the Vanderbilt Law School, 'not what was going on in the 1870s, when much of the legal curriculum was put in place.”'). See also Bronner, supra note 1. ("Robert L. Weinberg, a retired founding partner of the Washington law firm Williams \& Connolly and a lecturer at George Washington University Law School, said that ... law schools ought to greatly increase [the number of adjunct professors] because they bring real-world examples to students."); Dan Slater, At Law Firms, Reconsidering the Model for Associates' Pay, N.Y. TiMES, Apr. $1, \quad 2010, \quad$ at SPG 10, available at 
In the past, the legal employment landscape provided no incentive for law firms to question their traditional recruiting practices. The traditional law firm recruitment model — the summer associate program - is often little more than a glorified summer camp for some of the most highly educated-and debtridden-law students of our time. ${ }^{3}$ This summer-long social event often fails to provide students with a true depiction of life inside the law firm. ${ }^{4}$ Instead, the experience introduces the summer associate to isolated but "glamorous" aspects of legal matters, rather than assigning the students to perform necessary, but perhaps mundane, billable hours. ${ }^{5}$ Even in firms whose clients continue to allow them to bill for work performed by summer associates, a seasoned associate is often required to rework the majority of the student's work or reduce or delete time spent by the student from the final bill. ${ }^{6}$

http://www.nytimes.com/2010/04/01/business/01LEGAL.html?pagewanted=all\&_r=0

(" $[R]$ ecessionary pricing pressures, a trend away from hourly billing to flat fees and a technology revolution that has compelled in-house legal departments to compare costs of services and seek efficiencies have led many firms to rethink and, in some cases, radically restructure their associate programs. ... [F]irms . . . are experimenting with new ways to hire, train, promote and compensate associates.").

${ }^{3}$ David Lat, Crash Diet for Law Firms: Less Dessert for Summer Associates, N.Y. OBSERVER (May 6, 2008, 4:29 PM), http://observer.com/2008/05/crash-diet-for-law-firms-less-dessert-for-summerassociates/ ("The top firms pay their summers over $\$ 3,000$ a week- a week! - to enjoy three-hour lunches and surf the Web, and do a little bit of work on the side, but just a little, on the firm's most interesting and sexy matters. Don't forget the cooking lessons, wine tastings, pool parties, a clambake or a cruise-all of it carefully designed to create in these future lawyers a Pavlovian association between Big Law and Big Pleasure.") (emphasis in the original).

${ }^{4}$ Alison Monahan, The Inside Scoop on Law Firm Summer Associate Programs, GIRL's GuIDE TO L. SCH. (Aug. 19, 2011), http://thegirlsguidetolawschool.com/08/the-inside-scoop-on-law-firm-summerassociate-programs/ (“A summer associate position is an extended job interview.”).

${ }^{5} I d$. ("You can expect to do the sort of work a first year might do, without the really boring parts like document review. The expressed goal of the firm is to let you get a taste of what it would be like to work there. Their real goal is a bit different-it's to convince you that this firm is a reasonable place to work, which generally requires shielding you from the whole truth. So, most summers do a bit of 'real' work (carefully filtered to be relatively interesting and substantive), and spend a lot of time eating out and going to parties and sporting events.").

${ }^{6}$ Mark Herrmann, Inside Straigbt: On Summer Associates, ABOVE THE L. (Mar. 25, 2013, 10:07 AM), http://abovethelaw.com/2013/03/inside-straight-on-summer-associates/ ("It generally takes experience, training, and repetition to produce good quality work, so virtually all summer associates produce pretty mediocre stuff. Once in a blue moon, a summer associate would surprise me-but not often. When a summer associate gives me a crappy draft, I can't ask someone else to make it right; that would be bad recruiting. So I'm forced to edit the thing myself, retaining some semblance of the original so the kid won't leave my office in tears. I must then sit down with the kid for 60 or 90 minutes explaining all of the edits and concepts like 
Traditional summer-associate programs historically have emphasized entertainment over providing the summer associate with a realistic experience of life inside a law firm. ${ }^{7}$ Law students and law schools are realizing that the apprentice stage of legal education should provide a more valuable, tangible experience. $^{8}$ The students recently voiced their discontent in The American Lawyer's 2012 Summer Associate Survey, which reveals the students' desire to engage in legal work and to experience professional mentoring, while decreasing the number of over-the-top social events that are the norm. ${ }^{9}$

The problem of wasted summer work opportunities is compounded by another phenomenon, discussed by Dean Daniel Rodriguez of Northwestern University School of Law, who has openly questioned the value of the third year of law school. ${ }^{10}$ Rodriguez asserts that law schools must do more to provide substantive experiences and exposure to real-life legal matters to prepare their

'organizational structure,' 'topic sentence,' 'passive voice,' and other stuff that no one learned in school.”).

7 See Lat, supra note 3.

8 Segal, supra note 2 ("But those pushing for more practical content aren't looking for a bunch of classes in legal minutiae, nor do they expect client-ready lawyers to march off their campus. Instead, they would like to see less bias against professional training and more classes that engage the law as it exists today.”).

9 The 2012 Summer Associates Survey, AM. LAw. (Sept. 12, 2012), http://www.americanlawyer.com/PubArticleTAL.jsp?id=1202472306807\&The_2012_Summer_ Associates_Survey\&slreturn=20130504223035 ("Most of us would happily cut our workday short to go on a cruise. So would most of the law school students who spent this summer working at law firms across the country. But, according to this year's edition of The American Lanyer's annual Summer Associates Survey, some of these would-be lawyers have a different message for the hiring partners who brought them aboard. It's time to de-emphasize the fun. As one respondent said, 'I would ask that the Summer Associate Program be scheduled so that there is a bit more time for work.' A possible reason for the serious-minded pleas: the survey shows anxiety among summer associates at a four-year high. Who can have a good time with worry clouding their thoughts?").

${ }^{10}$ Daniel B. Rodriguez \& Samuel Estreicher, Make Law Schools Earn a Third Year, N.Y. TIMES, Jan. 18, 2013, at A27, available at http://www.nytimes.com/2013/01/18/opinion/practicing-lawshould-not-mean-living-in-bankruptcy.html ("Today, leaders of the New York bar, judges and law school faculty members will gather at New York University to discuss a proposed rule change. If adopted by the state's highest court, it could make law school far more accessible to low-income students, help the next generation of law students avoid a heavy burden of debt and lead to improvements in legal education across the United States. The proposal would amend the rules of the New York State Court of Appeals to allow students to take the state bar exam after two years of law school instead of the three now required.”). 
students for legal careers. ${ }^{11}$ Some law schools are catching on, while others have long integrated skills-based courses in their curriculums. ${ }^{12}$

\section{The University of Tennessee's ConCEnTRations in Advocacy and BUSINESS}

Long before Rodriguez issued this challenge to U.S. law schools, The University of Tennessee College of Law had been offering legal education programs that blend doctrinal substance and skills/competency training to prepare graduates to be, to a large degree, "practice ready." 13

11 Daniel B. Rodriguez, Clinicians Meeting, Word on the Streeterville (Apr. 29, 2013), http://deansblog.law.northwestern.edu/2013/04/29/clinicians-meeting/ ("In these times of serious scrutiny of the shape of legal education, focused attention on how to best develop and nurture live-client skills training is a high priority.").

12 Rodriguez \& Estreicher, supra note 11 ("Northwestern, for example, offers an accelerated program that lets students pursue a three-year course of study in two years, allowing them to take the bar and enter the job market a year earlier."); see also Stephen J. Harper, Practical Skills, BELlY OF THE BEAST (July 18, 2011), http://thelawyerbubble.com/2011/07/18/practical-skills/ ("Some schools are changing curriculum to develop skills that real lawyers need; that makes sense. . . . Stanford is considering a clinical course requirement involving 40 -hour plus weeks of actual case work, while Washington and Lee University of Law School replaced lectures and seminars with 'case-based simulations run by practicing lawyers."'); ELIZABETH G. Olson, Does Law School Have a Future? $\quad$ CNN MONEY (Dec. 18, 2012, 9:26 AM), http://management.fortune.cnn.com/2012/12/18/does-law-school-have-a-future/ ("Several prestigious law schools have targeted the third year for overhaul, including New York University's School of Law which, in October, agreed to open the third year of study to international experience, or work in a specialized area like environmental or antitrust law. Another cadre of students could choose to focus on specialties like patent or tax law Washington and Lee Law School adopted a revamped third year approach, so students can work at law clinics or internships at outside locations. Stanford Law School also broadened its third-year curriculum for students to earn joint degrees with other university departments."); infra note 13.

13 Clinical Programs, UnIV. Of TeNN. ColL. OF L., http://law.utk.edu/centers-clinics/ (last visited Oct. 11, 2013) ("For more than sixty years, the College of Law's Legal Clinics have provided law students with opportunities to learn by doing-representing clients and helping resolve legal disputes. Our legal clinic is the oldest continually operating clinical program in the nation. We offer eight clinics as well as three externship programs, providing a clinic opportunity for every willing student."); see also Center for Advocacy and Dispute Resolution, UNIV. OF TENN. COLL. OF L., http://law.utk.edu/centers-clinics/advocacy-center/ (last visited Oct. 11, 2013) ("In the 1990's giants in the Tennessee legal community envisioned a law school curriculum that would better prepare law students for a career in advocacy and dispute resolution."); Clayton Center Field Placement Opportunity, UNIV. OF TeNN. ColL. OF L., http://law.utk.edu/centers-clinics/claytoncenter/business-field-placement/ (last visited Oct. 11, 2013) ("The Center for Entrepreneurial Law, in partnership with the Y-12 National Security Complex and Oak Ridge National Laboratories in Oak Ridge, Tenn., as well as the University of Tennessee Athletics Department offers field placement opportunities for $2 \mathrm{~L}$ and $3 \mathrm{~L}$ students. The field placements consists [sic] of 
For example, the concentration in business transactions is a curricular pathway for law students at the College of Law who are interested in careers in law and business. ${ }^{14}$ It starts with courses that are staples of law schools everywhere-business associations, secured transactions, land finance, and taxand adds to them a number of "capstone" courses. These capstone courses feature simulations of sophisticated transactions in which third-year law students practice as lawyers to negotiate and document deals, drawing on the substance and skills that they have studied in their earlier coursework. ${ }^{15}$ For example, in an asset sale of a business module, one team of students might represent the seller, another team represents the buyer, and one team represents the lender financing the transaction, with the instructor or a confederate acting as the client making the business decisions.

In addition to the concentration in business transactions, the Clayton Center for Entrepreneurial Law has developed a number of advanced transactional drafting courses that follow its contract drafting course, itself one of the requirements for the concentration in business transactions. These courses, which have contract drafting as a prerequisite, include commercial leasing,

a one to four hour credit placement in the Fall or Spring Semester and may include a paid position at a competitive hourly rate in the following summer, working on the business and legal aspects of technology commercialization and technology transfer and athletic regulatory compliance.”).

${ }^{14}$ Concentration in Business Transactions, UNIV. OF TeNN. ColL. OF L., http://law.utk.edu/centersclinics/clayton-center/business-concentration/ (last visited Oct. 11, 2013) ("Since a high proportion of legal work occurs in the representation of businesses, the Business Transactions curriculum allows second- and third-year students to concentrate their studies on the legal aspects of business and finance, emphasizing the needs of business concerns both large and small. . . Following this course of study helps students develop competence in the kinds of transactional matters lawyers handle daily, such as working with clients in planning and carrying out business transactions, drafting and negotiating documents, and counseling clients about compliance with laws and regulations.").

${ }^{15} I d$. ("The curriculum allows students to prepare for practice in this field. Core doctrinal courses in Business Associations, Fundamental Concepts of Income Taxation, Taxation of Business Organizations, Land Finance Law, and Commercial Law are complimented by applied courses in Contract Drafting and Representing Enterprises. Students who have met the requirement of this concentration and the other requirements of the College will be acknowledged as having completed the J.D. degree with a concentration in Business Transactions.”). The capstone courses currently consist of representing enterprises, transactional tax planning, and the estate planning seminar. Business Transactions Curriculum, UnIV. OF TenN. Coll. OF L., http://law.utk.edu/centers-clinics/clayton-center/business-concentration/business-curriculum/ (last visited Oct. 11, 2013) (describing courses and recommending course sequence). 
construction law, mergers \& acquisitions, and, soon to be offered, software licensing.

Many of the faculty members that teach within the concentration-all of whom, like the rest of the full-time faculty of the College, are tenured or tenuretrack professors ${ }^{16}$ - have substantial practice experience with prestigious law firms and are well qualified to mold a curriculum that merges practical experience, black letter law, theory, and policy. ${ }^{17}$ The backbone of teaching in the basic contract drafting course and the advanced drafting courses, as well as in some of the modules of representing enterprises, is supplied by a robust pool of adjunct professors drawn from private practice and government offices, many of whom are alumni of the school and the concentration.

For students who plan to pursue a career in advocacy and dispute resolution, The University of Tennessee College of Law offers a similar concentration. The advocacy and dispute resolution concentration includes skillsbased courses in trial practice, pretrial litigation, negotiations, mediation, and interviewing and counseling, as well as many doctrinal courses such as evidence, criminal procedure, and alternative dispute resolution, each of which are taught utilizing an applied or problem-based methodology. ${ }^{18}$ The skills-based courses in

\footnotetext{
${ }^{16}$ The college's unified faculty tenure status is an important part of its culture. All full-time faculty appointments at the school, from doctrinal faculty to the legal clinic and the legal writing faculty, are tenured or tenure-track appointments. This has been instrumental in preventing the formation or perception of non-doctrinal faculty as being second-class citizens. This is unusual enough in the legal academy that, when recruiting new faculty, candidates have expressed disbelief or have been told by their colleagues at other institutions that it must not be true.
}

${ }^{17}$ Concentration in Business Transactions, supra note 14 ("Many of our faculty members have practiced with prestigious law firms in their transactional practice groups and are uniquely qualified to mold a curriculum that will give students practical experience in business law-from the perspectives of both transactional lawyers and commercial litigators. In part, the Business Transactions concentration was created to take advantage of these real-world experiences."). See also Our People, UnIV. OF TeNN. COLL. OF L., http://law.utk.edu/our-people/ (last visited Oct. 11, 2013) (listing professors with biographical and professional practice experience information).

${ }^{18}$ Curriculum, UNIV. OF TENN. COLL. OF L., http://law.utk.edu/advocacy-curriculum/ (last visited Oct. 11, 2013) ("Students who wish to complete the concentration in advocacy and dispute resolution must complete three requirements. First, students must begin the concentration during their second year of law studies by taking an applied evidence course which compliments their trial practice course. Both courses use the same practical materials which help the students to master and apply the rules of evidence while learning how to prepare and present a case for trial. Second, students must take an additional twelve hours of related courses. To satisfy this elective requirement, students may choose from additional concentration courses . . . including pretrial litigation, advanced trial practice, interviewing and counseling, negotiations, alternative dispute resolution, mediation, and advanced appellate advocacy; additionally, students may satisfy the elective requirement by taking special courses, designated as satisfying the elective requirement, 
the concentration are purposefully taught in small sections-having eight-totwelve students per class_-and are taught by full-time professors, civil and criminal practitioners, and state and federal judges. ${ }^{19}$

In order to complete the concentration and to graduate with an emphasis in advocacy and dispute resolution, students must participate in a six-hour client clinic or externship. ${ }^{20}$ The clinical, extern, and field placement opportunities at the College of Law are varied and numerous. ${ }^{21}$ Depending on their interests, students participate in externships in state or federal prosecution or public defender offices; in the advocacy clinic representing clients in juvenile, criminal, or housing matters; in the mediation clinic, mediating disputes in small claims court; or in the immigration clinic, representing clients in various immigration proceedings. Thus, students who graduate with a concentration in advocacy or dispute resolution will have learned and practiced requisite lawyering skills in a classroom and in a real-world setting.

which introduce them to emerging legal areas. Third, to complete the concentration, students must complete either a legal clinic or an externship. The clinical and externship programs give students the opportunity to represent clients and resolve disputes in a real-life setting while under the supervision of skilled instructors or practitioners.").

19 Center for Advocacy and Dispute Resolution, supra note 13 ("The Center offers a unique series of courses taught by an experienced faculty utilizing the College's state-of-the-art facilities. Members of the adjunct faculty include state and federal judges, private and public lawyers, and certified mediators .... The Center also provides extra-curricular programs for students and the legal community which includes [sic] a distinguished lecture series, multi-disciplinary symposia, and the popular 'Practice Series' in which judges and lawyers visit the law school for presentations and lunch with the students."); see also Full Time Faculty, Univ. OF Tenn. Coll. OF L., http://law.utk.edu/centers-clinics/advocacy-center/advocacy-faculty/ (last visited Oct. 11, 2013) (listing Center for Advocacy and Dispute Resolution full-time faculty, along with biographical information); Adjunct Faculty, UNIV. OF TENN. COLL. OF L., http://law.utk.edu/centersclinics/advocacy-center/adjunct-advocacy/ (last visited Oct. 11, 2013) (listing Center for Advocacy and Dispute Resolution adjunct faculty, along with biographical information).

20 Curriculum, supra note 18 (" $[\mathrm{T}]$ o complete the concentration, students must complete either a legal clinic or an externship. The clinical and externship programs give students the opportunity to represent clients and resolve disputes in a real-life setting while under the supervision of skilled instructors or practitioners.").

${ }^{21}$ Clinical Programs, supra note 13 ("We offer eight clinics as well as three externship programs, providing a clinic opportunity for every willing student: Advocacy Clinic, Business Law Clinic, Domestic Violence Clinic, Environmental Practicum, Externships, Immigration Clinic, Innocence/ Wrongful Convictions Clinic, Mediation Clinic, Homer A. Jones, Jr. Wills Clinic.”). 
Students at The University of Tennessee College of Law are not required to participate in a concentration; but, for those who do participate, they use their experiences in concentration courses to pursue advanced subjects like tax, corporate finance, intellectual property, federal courts, and the like. ${ }^{22}$ In any given year, up to two-thirds of the graduating class may complete one of the concentrations, with an even higher percentage of students completing all but one of the concentrations' requirements. The concentrations, combined with the number of clinical opportunities available at The University of Tennessee College of Law, are a provocative departure from the read-cases, attend-semi-Socraticlectures, and take-a-final exam model that dominates the majority of law school experiences.

\section{Waller's Schola2Juris AND NEW Waller Associate Summer Program}

Thinking along these same lines led the Nashville-based law firm of Waller Lansden Dortch \& Davis, LLP, to perform an autopsy on its summer program and to reinvent the way that it recruits associates. ${ }^{23}$ Waller found that the deficiencies leading to the decline of the summer program were in line with Dean Rodriguez's identified challenges, and the only remedy was to put the

22 Course of Instruction, UnIV. OF TENN. COLL. OF L., http://law.utk.edu/academicprograms/courses/courses-of-instruction/ (last visited Oct. 11, 2013) (listing course offerings).

23 Waller Lansden Takes Home Top Honors at Prestigious National Legal Marketing Awards Program, WALler LANSDEN DORTCH \& DAvis, LLP (Apr. 5, 2011), http://www.wallerlaw.com/NewsEvents/Press-Releases/28153/Waller-Lansden-Takes-Home-Top-Honors-at-Prestigious-

National-Legal-Marketing-Awards-Program [hereinafter Waller Lansden Top Honors] ("We launched Schola2Juris because we believed it was time to reinvent the law firm student recruiting process,' said Kathleen Pearson, Director of Professional Recruiting. 'In its first year, the program has made a tremendous impact on our firm and our clients by looking at recruiting in a new way. We're not only honored to win first place for Schola2Juris, but we're proud to have created a new model that could change the face of law firm recruiting across the nation.' . . Prior to launching Schola2Juris, Waller Lansden conducted extensive market research and worked closely with law schools to ensure the program was mutually beneficial. The firm gathered statistical information about AmLaw 200 hiring trends, total number of law school graduates and competitor hiring rates over the past 3 years. In addition, Waller Lansden leveraged social media-Facebook, Twitter and LinkedIn-to inform and educate students about the new program."). See also Tom Huddleston Jr., Waller Lansden Ready to Roll Out New Recruiting Program, AM L. DAILY (June 9, 2011, 12:44 PM), http://amlawdaily.typepad.com/amlawdaily/2011/06/wallerlansden recruiting.html ("Waller Lansden Dortch \& Davis is following through on plans to implement a new approach to recruiting under which it is moving away from the traditional on-campus interview model."); Schola2Juris: Overview, WALLER LANSDEN DORTCH \& DAVIS, LLP, http://www.wallerlaw.com/Join-Us/Schola2Juris (last visited Oct. 11, 2013) ("Schola2Juris is the first program of its kind—an apprenticeship designed to recruit law students with a dynamic program that truly focuses on mentoring and learning."). 
students to work on real matters and mentor them along the way. ${ }^{24}$ In order to pull off a drastic about-face in their program, the firm first ended their summer session altogether. Next, Waller reanimated its recruiting program and structured it around previous matters and transactions that the firm had already completed. ${ }^{25}$ The "Franken-summer" program that resulted was a thought-intensive scheme that took place during the students' $3 \mathrm{~L}$ fall semester. ${ }^{26}$ This initial ninety-degree pivot resulted in a cutting-edge approach to recruiting, named Schola2Juris, which put these final-year students to work on actual, closed matters that were previously handled by each of the firm's specific practice groups. ${ }^{27}$ Case files

24 Schola2Juris: Overview, supra note 23 ("Schola2Juris, which occurs during the Fall semester of a student's $3 \mathrm{~L}$ year, represents a significant shift from the antiquated model of summer associate programs. Waller has responded to demand from students, schools and clients that want to see time and resources invested in the advancement of students in order to make them real contributors from the first day they begin the practice of law.”). See also Huddleston Jr., supra note 23 (" $[\mathrm{T}]$ he shift away from the traditional model is significant. . . Kathleen Pearson, ... Waller Lansden's director of professional recruiting, says the new model could serve as an example to other firms looking for an alternative to on-campus recruiting.").

25 Schola2Juris: Overview, supra note 23 ("In order to build a stronger and more world-ready firstyear attorney, Waller leads apprentices through a program that is practice group specific and provides exposure to actual client matters that the firm has already handled from inception to completion. By working on projects developed from historical client matters, Schola2Juris participants are immersed in activity that is thought intensive, not hours intensive. We've done away with the old scenario in which summer associates are given time-sensitive assignments matters [sic] where their work is eventually written-off. This inefficient approach offered little educational benefit to the students and even less benefit to clients - in either the short or the long term.").

${ }^{26}$ Waller Lansden Top Honors, supra note 23 ("The six-week apprenticeship occurs during the fall of the third year of law school and is open to all students regardless of location."). See also Schola2Juris: Overview, supra note 23 ("Schola2Juris, which occurs during the Fall semester of a student's $3 \mathrm{~L}$ year, represents a significant shift from the antiquated model of summer associate programs. . . B By working on projects developed from historical client matters, Schola2Juris participants are immersed in activity that is thought intensive, not hours intensive."); Huddleston Jr., supra note 23 ("[T] he six-week apprenticeship program will run in the fall—from the beginning of September into October, while the hires are still in school.”).

27 Schola2Juris: Overview, supra note 23 ("In order to build a stronger and more world-ready first-year attorney, Waller leads apprentices through a program that is practice group specific."). See also Huddleston Jr., supra note 23 ("The openings are across all practice areas-finance, environmental/regulatory, tax, labor and employment, real estate, intellectual property, healthcare, litigation, and corporate. Waller Lansden has roughly 200 attorneys between its Nashville headquarters and its Birmingham, Ala. outpost.”); Elie Mystal, A New Approach to Fall Recruiting, ABOve THE L., (Sept. 8, 2010, 2:13 PM), http://abovethelaw.com/2010/09/a-new-approach-tofall-recruiting/ ("And did we mention that associates would be applying to specific positions and 
were redacted to protect client confidentiality and reformatted to allow for optimal teaching and mentoring opportunities. By using matters that the firm actually completed, attorneys were able to anticipate both the trouble spots in the exercise and where the ideal-teaching moments would occur. ${ }^{28}$ In this regard, the Schola2Juris program provided a very realistic experience for law students that enabled them to truly understand what the practice of law will entail as a junior to mid-level associate and created an apparatus for these students to take another step towards becoming profitable attorneys and integral members of their future practice areas.

The traditional summer associate program relies on law students working on specially selected projects that are not an accurate representation of life as an associate, and all too often, graduating law students succumb to this "bait and switch."29 By structuring the Schola2Juris program to allow students to work through a matter from its inception to its close, participants walked in the shoes

practice areas?"); Martha Neil, Law Firm's Innovative Recruiting idea: Shift Summer Program to 3L Fall, Offer Remote Options, ABA J., (Sept. 8, 2010, 7:20 PM), http://www.abajournal.com/news/article/law_firms__innovative__ recruiting_idea _shift_summer_program_to_31_fall_offer_("The program is predicated on applying for available post-graduation jobs at the firm[ and geared to offering apprenticeships in specific practice areas.").

28 See Schola2Juris: Overview, supra note 23 ("In order to build a stronger and more world-ready firstyear attorney, Waller leads apprentices through a program that is practice group specific and provides exposure to actual client matters that the firm has already handled from inception to completion. By working on projects developed from historical client matters, Schola2Juris participants are immersed in activity that is thought intensive, not hours intensive. We've done away with the old scenario in which summer associates are given time-sensitive assignments matters [sic] where their work is eventually written-off. This inefficient approach offered little educational benefit to the students and even less benefit to clients - in either the short or the long term.”).

${ }^{29}$ Kathleen Pearson, Schola2Juris_Can You Really Recruit Students in Three and a Half Months?, WALLER LANSDEN \& DORTCH DAVIS, LLP, http://www.wallerlaw.com/portalresource/Schola2Juris_Article (last visited Oct. 11, 2013) ("I heard a lot of stories about people who went to work at law firms expecting to practice in one area who ended up being shuffled around to a practice area that didn't really fit their talents and interests."); see also Huddleston Jr., supra note 23 ("The benefit of bringing in students who are both further along in law school and targeted to a specific practice is that it allows the firm to hire based on current needs. The alternatives: shuffling associates to fill roles for which they weren't originally recruited or hiring laterals to fill unexpected openings."). 
of attorneys at all levels-from the first-year associate up through the senior associate ranks. ${ }^{30}$

Offering students an opportunity to learn from actual deals was only one motivation for rethinking the summer program. Because the apprenticeship took place during third-year students' fall semester, less than ten months from their graduation, the firm was in an ideal position to forecast future staffing needs with greater certainty. ${ }^{31}$ Moreover, apprenticeships in the Schola2Juris program were offered only in the practice areas where first-year associate positions would be available following graduation. ${ }^{32}$ The firm requires students to apply for an apprenticeship in a particular area, forcing candidates to carefully consider and contemplate the practice area in which they were truly interested. ${ }^{33}$ With this approach, students could dive into the myriad of aspects that arose in the closed matter and the issues that were handled by the practice group of their choosing, rather than merely gaining surface-level experience across a multitude of practice groups. Following the six-week apprenticeship, Waller awarded each apprentice a $\$ 10,000$ scholarship, and permanent job offers were extended to students based on performance. ${ }^{34}$

30 Pearson, supra note 29 ("Each practice group designed a training project based on matters similar to those typically handled in its respective area. Each apprentice worked on assignments that spanned the life of a client matter from start to finish. This provided the apprentices with a more complete idea of the type of matters handled by the group, how their work fit [sic] into the whole picture, and how the attorney teams work together.").

${ }^{31}$ Mystal, supra note 27 ("You are applying for positions the firm knows it needs to fill, not jobs the firm hopes will be available."); see also Zach Lowe, Waller Lansden Shakes Up Recruiting, AM L. DAILY (Sept. $\quad 8, \quad 2010, \quad$ 5:03 http://amlawdaily.typepad.com/amlawdaily/2010/09/wallerlandsen.html ("The firm will pick those 3Ls based on real full-time associate job openings at the firm.”).

32 Huddleston Jr., supra note 23 ("Schola2Juris [is] an apprenticeship program announced last fall that will see the firm hire only 3 Ls based on actual full-time openings.").

33 Mystal, supra note 27 ("And did we mention that associates would be applying to specific positions and practice areas? No more of this 'rotation' through multiple departments, practice groups, or even offices, as summers continue the charade that they have even a marginal idea of what kind of law they want to practice. You want in on the M\&A group? We've got one opening and three applicants; fight it out for six weeks like freaking adults!”).

${ }^{34}$ Philip Nannie, Waller Lansden Seeks Applicants for Schola2Juris, POSTBUSINESS (June 20, 2011), http://nashvillepost.com/blogs/postbusiness/2011/6/20/waller_lansden_seeks_applicants_for_ schola2juris ("At the end of the program, job offers will be made based on performance."). 
To finally complete the overhaul of their summer internship and take the program in a new direction, Waller is now embarking on the final pivot in this one-hundred-eighty-degree turn: they are bringing the Schola2Juris premise back to the summer. The new Waller Associate Summer Program will maintain and enhance the benefits and practical experiences offered by the Schola2Juris program while providing the students with more flexibility and relationshipbuilding opportunities across practice groups.

The focus is still on making students as practice ready from day one as possible by training them on reformatted matters that are practice group specific, but now students will be working at the firm, five days per week, during the second half of the summer. While Schola2Juris insisted that students apply to one practice group per the firms forecasted hiring needs, the new Waller Associate Summer Program will interview and make offers in the fall to secondyear students to join the firm. Similar to the Schola2Juris approach to hiring, Waller will announce in the spring which groups will likely have entry level needs relevant to that classes graduation date and give the selected students the opportunity to request placement in one of those particular groups. This matching process, the firm hopes, will give students and practice groups a head start in determining where to spend the majority of their time that summer, instead of chasing down practice groups that do not expect to have the need for a first-year attorney.

These students will again work alongside a particular practice group on their prior matters or deals, but the summer will consist of two, three-week sections, essentially providing for two Schola2Juris-like experiences with different practice areas. This makes up approximately $60 \%$ of the summer program; with the remaining time, students will be staffed on live matters, attend hearings, client meetings and other time sensitive issues with their groups or with one or more of the groups that they are not embedded in. At completion of the summer, the firm will give permanent offers based on performance in the program and other factors drawn out of attorney evaluations. In keeping with the Schola2Juris model, the firm intends to hire only as many students as they foresee hiring full time. If the unfortunate occurs and one or more of those students do not earn permanent offers, the firm will staff through other avenues such as late season on-campus recruiting or lateral recruiting at the junior level ranks.

\section{CONCLUSION}

The students at The University of Tennessee College of Law that participate in all or part of the concentrations in advocacy and dispute resolution or business transactions and the apprentices that participate in the evolved Waller 
Associate Summer Program walk away with more than a law degree, a job, and some new skills. They gain practical experience that goes a long way towards becoming a more practice-ready associate that can contribute from day one. ${ }^{35} \mathrm{We}$ are in a new era, one where a law or medical degree is just the beginning of the journey, and not the gateway to job security and high achievement. ${ }^{36}$ Students, professionals, law schools, and law firms must begin to require more of each other, instead of simply pointing fingers when employment statistics can no longer counterbalance staggering debt. ${ }^{37}$ Of course, the only way that our institutions and current practices will improve is through constant introspection

35 Schola2Juris: Overview, supra note 23 ("In order to build a stronger and more world-ready first-year attorney, Waller leads apprentices through a program that is practice group specific and provides exposure to actual client matters that the firm has already handled from inception to completion."); see also Huddleston Jr., supra note 23 ("The hires will complete training modules created by each practice group that will offer apprentices a simulated experience meant to reflect the type of work they would perform as full-time associates, Pearson says.”).

36 Sabiha Khan, Law Degree Does Not Guarantee a Successful Career in Current Job Market, DAILY BRUIN, (Feb. 22, 2011, 11:10 PM), http://dailybruin.com/2011/02/22/law_degree_does_not _guarantee_a_successful_career_in_current_job_market ("While many students enter professional schools because of the greater potential for job security and a lucrative career, law school does not guarantee that outcome. It's no surprise that college graduates are facing a grim job market, but law school grads are facing something even scarier-a mountain of debt. . . S Students traditionally justify these debts with the prospect of higher paying jobs at the end of the tunnel. A law degree offers a certain sense of security.... However, a law degree is not necessarily a 'golden ticket.' Once the reality of debt settles in, options are limited for students, although many are initially attracted to law school because of the supposed versatility of a J.D. . . Undergraduate students should be aware of the fact that, even with a graduate degree in hand, the job market is still very tough. And debt is not easy to pay off."). See also William D. Henderson \& Rachel M. Zahorsky, The Law School Bubble: How Long Will It Last if Law Grads Can't Pay Bills?, ABA J., Jan. 1, 2012, 6:20 AM), http://www.abajournal.com/magazine/article/the_law_school_bubble _how_long_will_it_last_if_law_grads_cant_pay_bills (“Law students, along with medical and dental students, are treated generously as future professionals and able to borrow, with virtually no cap, significantly more money than undergrads. America’s law students borrowed at least $\$ 3.7$ billion in 2010 to pay for their legal educations. Although the majority of the funds came from the Education Department, the patchwork of mechanisms that serve higher education as a whole make it difficult to regulate how much is being lent and to whom.").

37 Henderson \& Zahorsky, supra note 36 ("In 2010, 85 percent of law graduates from ABAaccredited schools boasted an average debt load of $\$ 98,500$, according to data collected from law schools by U.S. News \& World Report. At 29 schools, that amount exceeded $\$ 120,000$. In contrast, only 68 percent of those grads reported employment in positions that require a JD nine months after commencement. Less than 51 percent found employment in private law firms.”). 
and challenges to ourselves to raise the bar. ${ }^{38}$ While the jury is out as to whether these approaches blaze a new trail in the collective development of legal education and legal internships in the country, these three programs represent a significant step in the system's evolution, and each has roots that extend long before the current crisis.

38 Bruce Anikowiak, Law Schools Must Reform: They Need to Leave the Ivory Tower and Teach Practical Lanyering, Pittsburgh Post-Gazette (Jan. 4, 2012, 12:00 AM), http://www.postgazette.com/stories/opinion/perspectives/law-schools-must-reform-280315/ ("As more and more law students graduate with a diploma in one hand, significant student loan debt in the other and no true 'law job' in the offing, law schools are forced to confront a deeply moral dilemma. As a law professor and former law student, I recognize that, beyond tuition, students invest a deep faith in us that the enormous sacrifices they make to earn their degree will allow them to do the work of justice that drew them to the law in the first place. Law schools are morally obliged to justify that investment of faith. ... Teaching this art requires considerable effort and a profound redefinition of our identity as institutions embedded in the legal profession in a way in which we can have the most impact: by sending into practice young lawyers ready to be champions of justice from day one of their careers."); see also A. Benjamin Spencer, Guest Post: Reform Law Schools, Don't Deregulate Them, WASH. POST (Nov. 7, 2011, 11:45 AM), http://www.washingtonpost.com/blogs/college-inc/post/guest-post-reform-law-schools-dontderegulate-them/2011/11/07/gIQAxF5 XvM _ blog.html ("Some might argue that today we have an abundance of law schools of varying quality churning out graduates who are not ready to practice and who can't get jobs. But if that is true-and it may be-how would formally deregulating the industry make the situation better? Doing so would allow even lower standards; costs would drop, but so would quality. This is unacceptable; quality legal services help ensure the rule of law in our democracy. The better solution is to reform law schools by offering a better balance of the doctrinal, skills, and values education that students need to become competent legal professionals. The American Bar Association, in its role as accreditor of law schools, should make sure its standards allow the freedom to make these changes."). 